\title{
Managing and engineering complex technological systems: a review
}

\author{
Ghulam Abbas ${ }^{*}$ (10
}

*Correspondence: abbasg@giki.edu.pk Faculty of Computer Sciences and Engineering, GIK Institute of Engineering Sciences and Technology, Topi 23640, Pakistan

\author{
Book details \\ Zonnenshain A, Stauber S. \\ Managing and Engineering Complex Technological Systems. \\ John Wiley \& Sons, Inc., Hoboken, New Jersey, USA; 2015. \\ 240 pages, ISBN: 978-1-119-06859-4.
}

Keywords: Complex systems, Systems engineering, Systems management, System of systems

\section{Overview}

Systems engineering (SE) is an interdisciplinary approach to cope with the ever-increasing complexities of technological systems. The field of SE has imparted valuable insights on optimizing and analyzing complex systems, which have greatly benefited from the methodologies and principles of SE. The approach of SE is to combine classical engineering considerations with the stipulated constraints and traditional challenges faced by organizational and managerial systems to enable the development of successful largescale complex systems (Luzeaux et al. 2011; Naser and Kamrani 2012). In this regard, non-technical readers also need to grasp a picture of SE to understand its benefits and employ modern insights and tools to optimize systems.

There is only a handful of books, such as Eisner (2008), Sage and Rouse (2009), Parnell et al. (2011), Khisty et al. (2012), and Blanchard and Blyler (2016), which combine the theory and practice of SE and systems management. To that end, "managing and engineering complex technological systems", by Zonnenshain and Stauber, is the book that for the first time presents a qualitative study of the different aspects of SE, accomplished through dozens of comprehensive interviews with renowned experts, leading systems engineers and experienced consultants in the field.

\section{Review}

The book is organized in three parts. The first part is a generic overview of the field of SE, outlining the characteristics, history and future of the field. The second part discusses two significant defense system projects as case studies and the third part presents the detailed interviews.

(c) 2016 The Author(s). This article is distributed under the terms of the Creative Commons Attribution 4.0 International License (http://creativecommons.org/licenses/by/4.0/), which permits unrestricted use, distribution, and reproduction in any medium, provided you give appropriate credit to the original author(s) and the source, provide a link to the Creative Commons license, and indicate if changes were made. 


\section{Part I}

This part is based on the insights derived from the interviews. The first chapter in this part presents the origins, history, essence and types of SE. In the second chapter, a multidisciplinary systematic view is presented, which includes the boundaries of a system, system of systems and managing the human factor. The role of a systems engineer as a manager and leader is presented in the third chapter. The topic of the fourth chapter is the evolution of a systems engineer. The fifth chapter presents SE in various organizations and the last chapter in this part outlines the future of SE.

\section{Part II}

The first chapter in this part reviews the IAI Lavi Project, and the second chapter is on the successfully completed Iron Dome Project.

\section{Part III}

The first chapter in this part consists of SE to address the challenges of a complex technological worlds of the space and aviation industries. The second chapter in this part is on the development of SE in commerce and industry, and in complex civil systems. The third chapter consists of the influence of the exponential growth of the computing world on SE processes. The forth chapter in on SE and the academic world. The last chapter in this part is on SE in the worlds of training and consulting.

\section{Price}

The book is available both in print and electronically. The prices are affordable not only for the libraries but also for individuals, which makes this book an easily accessible choice for the readers.

\section{Conclusion}

The book by Zonnenshain and Stauber documents various aspects of the study of SE and presents a broader view of the challenges faced, and the benefits offered, by SE. The interviews assist the reader learn from the experience, opinions and insights of the renowned experts in the field, and to adopt the methods of conduct suited to each reader's area of activity. Readers from outside the SE community can also understand the insights and findings contained in this book and can even apply the findings to their respective occupational areas.

Abbreviation

SE: systems engineering.

\section{Authors' information}

Ghulam Abbas received the B.S. degree in computer science from University of Peshawar, Pakistan, in 2003, and the M.S. degree in distributed systems and the Ph.D. degree in computer networks from the University of Liverpool, U.K., in 2005 and 2010, respectively. From 2006 to 2010, he was Research Associate with Liverpool Hope University, U.K., where he was associated with the Intelligent \& Distributed Systems Laboratory. Since 2011, he is with GIK Institute of Engineering Sciences and Technology Pakistan, and is currently working as Associate Professor and Director Information Technology. Dr. Abbas is a Fellow of the Institute of Science \& Technology, U.K., and a Senior Member of the IEEE Computer and Communications Societies. His research interests include Internet architecture, congestion control, active queue management and routing.

Acknowledgements

None. 


\section{Competing interests}

The author declare that he has no competing interests.

\section{Funding}

No funding sources are available.

Received: 18 August 2016 Accepted: 19 August 2016

Published online: 25 August 2016

\section{References}

Blanchard BS, Blyler JE (2016) System engineering management. Wiley, Hoboken

Eisner DH (2008) Essentials of project and systems engineering management. Wiley, Hoboken

Khisty CJ, Mohammadi J, Amedkudzi AA (2012) Systems engineering: with economics, probability, and statistics. J. Ross Publishing, New York

Luzeaux D, Ruault J-R, Wippler J-L (2011) Complex systems and systems of systems engineering. ISTE Ltd., London

Naser A, Kamrani AK (2012) Introduction to systems engineering. In: Intelligent transportation and evacuation planning. Springer, Berlin, p 1-17

Parnell GS, Driscoll PJ, Henderson DL (2011) Decision making in systems engineering and management. Wiley, Hoboken Sage AP, Rouse WB (2009) Handbook of systems engineering and management. Wiley, Hoboken

\section{Submit your manuscript to a SpringerOpen ${ }^{\circ}$} journal and benefit from:

- Convenient online submission

\section{- Rigorous peer review}

- Immediate publication on acceptance

- Open access: articles freely available online

- High visibility within the field

- Retaining the copyright to your article

Submit your next manuscript at $\boldsymbol{\nabla}$ springeropen.com 